\title{
CUL1 wt Allele
}

National Cancer Institute

\section{Source}

National Cancer Institute. CUL1 wt Allele. NCI Thesaurus. Code C52062.

Human CUL1 wild-type allele is located in the vicinity of 7q36.1 and is approximately 102 $\mathrm{kb}$ in length. This allele, which encodes cullin-1 protein, plays a role in regulating the ubiquitination of proteins involved in cell cycle progression, signal transduction and transcription. 